\title{
A PIONEER USAGE OF GOLD NANOPARTICLES IN SANDWICH ELISA BASED ON CIRCULATING HYDATID ANTIGEN AS A TOOL FOR IMPROVEMENT OF SERODIAGNOSTIC TESTING
}

\section{By}

SAMIA M. RASHED ${ }^{1}$, MONA E. NASR ${ }^{1}$, IBRAHIM R. A. SHALASH ${ }^{2}$, NAGWA S. M. ALI', AMIRA S. G. ELGHANNAM ${ }^{1}$, AND WALEED E. ELAWAMY ${ }^{1,3 *}$ Department of Parasitology, Faculty of Medicine, Benha University ${ }^{1}$, Postal code 13512, Benha and Department of Immuno-Parasitology, Theodore Bilharz Research Institute ${ }^{2}$, Embaba P. O. Box 30 Giza, Egypt and Department of Pathology (Microbiology unit), College of Medicine, Jouf University ${ }^{3}$, Sakaka, Aljouf, Postal code 72341

Saudi Arabia ( ${ }^{*}$ Correspondence: waleedelawamy2015@yahoo.com, Phone: +966590997875; ORCID: 0000-0002-5838-0494)

\section{Abstract}

Human cystic echinococcosis is a zoonosis occurring due to dogs handling and exposure to Echinococcus granulosus ova in their stools being an accidental intermediate host. Serology remains the only sure and important tool to diagnose this disease. We aimed to improve the detection of circulating antigen by sandwich ELISA through its binding to gold nanoparticle and proving the role of minute nanoparticles in serodiagnosis. Gold nanoparticles (AuNPs) were employed for the capture of the antigens of protoscolices (pAg) in the patient's serum by sandwich ELISA. Cross-reactivity for antigens from Hymenolepis nana, Entrobius vermicularis, and Fasciola gigantica was ruled out by using anti-protoscolices polyclonal IgG antibodies ( $\mathrm{ppAb}$ ). Antigen of sonicated protoscolices which were removed from camel lung cysts, was purified and injected to a New-zealand white rabbit giving ppAb which then loaded on AuNPs being used as a diagnostic indicator for circulating pAg by both sandwich ELISA and nanogold sandwich ELISA techniques. Nanogold sandwich ELISA was able to give positive results with $96.3 \%$ of hydatid patients and $5 \%$ of non-hydatid patients while sandwich ELISA showed $81.4 \%$ and $20 \%$ positive cases of the same groups respectively. The sensitivity and specificity of nanogold sandwich ELISA were $96.3 \%$ \& $95 \%$ against $81.5 \%$ \& $80 \%$ for those of sandwich ELISA respectively. The conjugation of AuNPs to anti-Echinococcus IgG antibodies seems to be beneficial to increase PPV, NPV, and efficiency and reduce the overall cost of the assay as less antibody was needed.

Keywords: Hydatidosis, Protoscolices antigen, polyclonal IgG, Gold nanoparticles, Sandwich ELISA

\section{Introduction}

Cystic echinococcosis (CE) is endemic in many countries, including the Mediterranean basin, Latin America and Central Asia (Salama et al, 2014). In Egypt, CE is an endemic disease in animals (Omar et al, 2013) and man (Ibrahim and Morsy, 2020) Diagnosis of CE depended on clinical pictures and serodi agnosis and the development of reliable serodiagnostic technique was a must (Khanbabaie et al, 2019). Monitoring of hydatid fluid to react against IgG antibodies was used for hydatidosis diagnosis but of less value as the antibodies persist for long time in sera as well as of false positive and negative results (Hernández-González et al, 2018). Clinical hydatidosis diagnosis was vague and not acc- urate in diagnosis due to cross-clinical pictures with other hepatic parasites (El-Sayed $e t$ $a l$, 2019), hence always supported by imaging and serodiagnosis but depending on immunodiagnostic tests to detect anti-hydatid antibodies gave less specificity and sensitivity in infected cases (Koura et al, 2015).

Due to lack of target antigen standardization in hydatid infections which is generally formed of crude antigen preparation of hydatid fluid inside cysts, there was an urgent need for the development of new tools among many immunodiagnostic tests which are commercially available to overcome this lack (Pagnozzi et al, 2016). The purified hydatid cyst fluid antigen was reliable in hydatidosis serodiagnosis compared to whole hy- 
datid cyst fluid (Iraqi, 2016).

The use of nanotechnology in immunodiagnostic studies gave high sensitivity in detection of target analyzing specific to pathogens and micro-organisms with the advantages of nanomaterial properties allowed rapid detection even in small sample size (Aly et al, 2013). The nanoparticles as labels facilitated test proved useful to detect infectious agents with low costs than already used technologies (Abraham et al, 2008).

Antigen detection in hydatidosis became useful for serodiagnosis and also can be used for post-treatment follow up hence it improved the diagnostic abilities when used together with antibody detection tests. Latex agglutination test was used as a diagnostic test for $\mathrm{CE}$ and the revealed results were functi onalized as a simple and rapid diagnostic tool to confirm that a suspected cyst being hydatid one (Chandrakesan and Parija, 2003). Sandwich ELISA with paramagnetic nanoparticles provided an extraordinary tool for improving the sensitivity of hydatidosis antigen detection thus making benefits of the high binding capacity of magnetic beads in enhancing the antigen detection sensitivity (Koura et al, 2015). Lateral flow dipstick was developed to detect three types of hydatid antigen including: hydatid cyst fluid, native antigen $\mathrm{B}$ and recombinant antigen $\mathrm{B}$, thus after a series of optimizations a combination of anti-native antigen B-IgG and goldconjugated anti-hydatid cyst fluid IgG was used to develop lateral flow dipstick assay (Khanbabaie et al, 2019). A number of recombinant antigens mainly derived from hydatid fluid improved performances and standardizations of the serological tests, among them B2t \& 2B2t antigens (HernándezGonzález et al, 2018). A new recombinant fusion protein was developed using coding sequence of antigen B2t and two sequences of EPC1 antigen evaluated by indirect ELISA test for sera from patients with hepatic CE (Fathi et al, 2018).

Covalent conjugation of antibodies to gold nanoparticles has more advantages over pas- sive adsorption with higher stability, less co st, and reproduced conjugated antibodies reliable quantitation of analyses for best sensitivity (Hermanson, 2008).

The present work aimed to improve the capacity of sandwich ELISA in detection of hydatid protoscolices antigen in human sera by labeling anti-Echinococcus IgG polyclonal antibody on gold nanoparticles.

\section{Materials and Methods}

Protoscolices antigen production: Deposit of hydatid fluid from camel lung cysts containing protoscolices was exposed to freezing and thawing 3 times and use 10 times of its volume of $0.15 \mathrm{M}$ phosphate buffer saline (PBS) to wash, $\mathrm{pH} 7.2$ then sonicated by 150 $\mathrm{W}$ ultrasonic disintegrator and the sonicate was sedimented at $10000 \mathrm{~g}$ for 30 minutes, the supernatant was split into aliquots and stored at $-20^{\circ} \mathrm{C}$ (Rafiei and Craig, 2002).

pAg purification by diethyl-amino-ethylsephadex (DEAE-Sephadex A50) chromategraphy: Removal of cross-reactive proteins and host components from Echinococcus antigens was purification (Jeyathilakan et al, 2014). DEAE Sephadex A 50 chromatography was used to purify the camel hydatid cysts antigens based on their charges, thus DEAE group maintained positive charges were neutralized by negative chloride charges (Smith et al, 1993). Anion exchange chromatography was done by adding $0.5 \mathrm{gm}$ DEAE Sephadex A 50 powder (Pharmacia, Uppsala, Sweden) to $200 \mathrm{ml}$ of $0.5 \mathrm{M}$ Tris$\mathrm{HCl}$ buffer (Bio-Rad) adjusted at $\mathrm{pH} 7$ slowly for 1-2days at $4{ }^{\circ} \mathrm{C}$ the Sephadex was swollen to $22 \mathrm{ml}$ beads. In a $30 \times 2.5$ column, swollen beads suspension was poured using a glass rod to avoid air bubbles trapping, and covered by binding buffer $(20 \mathrm{mM}$ Tris$\mathrm{HCl})$. Hydatid antigen sample was dialyzed versus binding buffer allowed to penetrate beads, washed by eluting buffer $(20 \mathrm{mM}$ Tris- $\mathrm{HCl} / 150 \mathrm{mM} \mathrm{NaCl}$ ) and serum sample protein was calculated by collecting 10 fractions each in $2 \mathrm{ml}$ using spectrophotometer (Perkin Elmer Lambda 1 A). Absorbance at $280 \mathrm{~nm}$ for each fraction was measured and 
peak fractions of high absorbance were pooled together and the protein content was estimated by BioRad protein assay (Sadjjadi et al, 2009).

Indirect ELISA was used to assess the pAg reactivity (Engvall and Perlmann, 1971) against diluted human sera to confirm hydatidosis by C.T, Sonar, IHAT, and surgical biopsy (G1 individuals). Characterization of protoscolex antigen by SDS-PAGE showed three differ-rent protein bands represented purified protoscolex antigen. Anti-E. granulosus IgG ppAb was purified with $12.5 \%$ SDS-PAGE and antibody was other proteins free (Koura et al, 2015). Absorbance was measured at $492 \mathrm{~nm}$ by ELISA reader (BioRad microplate reader, Richmond Co., Wilmington, USA), and positivity cutoff point was the mean optical density reading.

Immunization of a rabbit and construction of ppAb: A New Zealand white male rabbit parasites free was purchased from Rabbit Research Unit, Faculty of Agriculture, Cairo University. Experiment duration was 4 weeks under standard laboratory care at $21^{\circ} \mathrm{C}$, $16 \%$ moisture, filtered drinking water with salt $(1 \mathrm{~cm} / 5$ liter $) \&$ vitamins $(1 \mathrm{~cm} / 10$ liter $)$, and diet contained $15 \%$ protein, $3 \%$ fat $\&$ $22 \%$ fiber. A rabbit was immunized by I.M. injection of a priming dose of $1 \mathrm{mg}$ purified pAg mixed with a similar volume of complete Freund's adjuvant (Sigma), then a first booster dose of $0.5 \mathrm{mg} \mathrm{pAg}$ was given two weeks after priming dose and two booster doses of $0.5 \mathrm{mg} \mathrm{pAg}$ at weekly intervals (Fagbemi, 1995). Three days after last immunization, the blood sample was taken and centrifuged at $4000 \mathrm{~g}$ for $15 \mathrm{~min}$. and serum IgG ppAb was fractionated and kept at $-20^{\circ} \mathrm{C}$. Protein content was estimated by Bradford dye-binding procedure using color change of Coomassie Brilliant Blue G-250 dye by reference to a standard curve consisting of known concentrations of purified protein by using a protein assay kit (Bradford, 1976). Rabbit was exposed to euthanasia by I.V. injection of phenobarbital sodium at experimental end it suffered from severe pain duri- ng experimentation and not re-used again.

Isolation of rabbit ppAb: As a result of polar and ionic groups of proteins, their solutions form hydrogen bonds in water and adding highly charged ions such as ammonium sulfate, to compete with proteins to bind water and precipitated water molecules from proteins (Nowotny, 1979). Saturated ammonium sulfate solution $\left(\mathrm{NH}_{4}\right)_{2} \mathrm{SO}_{4}$ was mixed with rabbit serum, centrifuged at $3500 \mathrm{~g}$ for $20 \mathrm{~min}$. at $4^{\circ} \mathrm{C}$ in cooling centrifuge (Heraues), supernatant was discarded and repeated precipitations, final precipitate was dissolved in $0.01 \mathrm{M}$ PBS, pH $7.2 \&\left(\mathrm{NH}_{4}\right)_{2} \mathrm{SO}_{4}$ was dialyzed against $0.01 \mathrm{M}$ PBS, $\mathrm{pH} 7.2$ for 72 hrs to get pure protein (Nowotny, 1979). The protein content in isolated IgG ppAb after ammonium sulfate treatment was determined by dye-binding procedure (Bradford, 1976).

Labeling of ppAb with Horse Radish Peroxidase (HRP): IgG ppAb molecules were conjugated to HRP (Sigma) enzyme exploiting its glycoprotein nature, and enzyme saccharide residues were oxidized by sodium periodate to give aldehyde groups that reacted with IgG molecule amino groups and led to Schiff bases production reduced to high molecular weight conjugate (Wisdom, 2009). Labelling was done on two successive days (Tijssen and Kurstak, 1984) on $1^{\text {st }}$ day, $5 \mathrm{mg}$ of HRP was dissolved in $1.2 \mathrm{ml}$ distilled water (dist. $\mathrm{H}_{2} \mathrm{O}$ ) then $0.2 \mathrm{ml}$ sodium periodate was added for $20 \mathrm{~min}$. at room temperature and dialysis against $1 \mathrm{mM}$ sodium acetate buffer, $\mathrm{pH} 4$ at $4^{\circ} \mathrm{C}$ overnight to give solution (A). $5 \mathrm{mg} / \mathrm{ml}$ of $\mathrm{IgG}$ ppAb was dialyzed against $0.02 \mathrm{M}$ carbonate buffer, $\mathrm{pH} 9.6$ at $4{ }^{\circ} \mathrm{C}$ overnight to give solution (B). On $2^{\text {nd }}$ day, solution (A) was mixed with solution (B) at room temperature for $2 \mathrm{hrs}$ and $0.1 \mathrm{ml}$ of sodium borohydride was added to the mixture, finally dialyzed against $0.01 \mathrm{M}$ of PBS, pH 7.2 at $4{ }^{\circ} \mathrm{C}$ overnight and the resulting conjugate was stored at $-20^{\circ} \mathrm{C}$ till used.

Synthesis of antibody-AuNPs conjugates: AuNPs (40nm/particle) were purchased in form of gold $\mathrm{HCl}$ solution with $3.08 \times 10^{8}$ pa- 
rticles/ml (Nano Tech. Co, Egypt). Loading of IgG ppAb on AuNPs (Hermanson 2008), all glass wares were soaked with Aqua Regia (PanReac, Germany) for overnight and on next day rinsed with tap water, the hydrogen tetrachloroaurate III $\left(\mathrm{HAuCl}_{4}\right)$ solution was vortexed and $250 \mathrm{ml}$ of it was added in a round bottom flask, condensed for $1 \mathrm{hr}$, refluxed using a sand bath, then $25 \mathrm{ml}$ of $38.8 \mathrm{mM}$ sodium citrate were added and the flask was left to reflux again for $15 \mathrm{~min}$. and stored in a dark place. Functionalization of $30 \mathrm{ml}$ of AuNPs solution with $45 \mu \mathrm{l}$ of $1 \mathrm{mM}$ mercaptoundecanoic acid (MUA) in ethanol (Sigma, Aldrich, Germany) overnight at $4{ }^{\circ} \mathrm{C}$ and AuNPs concentration was determined before and after functionalization by UV/vis spectrophotometry using Beer's law (Zhou et al, 2009). Covalent Conjugation of ppAb with AuNPs-MUA was done by adding $5 \mathrm{ml}$ of AuNPs-MUA to $2 \mathrm{ml}$ of ppAb in presence of N-hydroxy Succinimide/1-Ethyl 3-Dimethylaminopropyl Carbodiimide (NHS/EDC) as covalent cross-linkers (Fluka, Germany) to obtain powerfully built AuNPs-MUA conjugates, by adding $5 \mathrm{ml}$ of ppAb-AuNPs conjugates to $5 \mathrm{ml}$ of a mixture $(5 \mathrm{mM}$ sodium phosphate buffer $=\mathrm{pH} 7,1.2 \mathrm{mM}$ NHS $\&$ $2.8 \mathrm{mM}$ EDC), left overnight at $4{ }^{\circ} \mathrm{C}$ to elicit electrostatic binding between $\mathrm{ppAb}$ and AuNPs-MUA (Mukher- jee et al, 2005).

Quantitation of protein after conjugation of ppAb with AuNPs: Based on Bradford dye-binding procedure, quantitation of protein content in ppAb-AuNPs conjugates was done by preparing standards of protein samples in form of serial dilutions of bovine serum albumin (BSA) with dist. $\mathrm{H}_{2} \mathrm{O}$ as (BSA: $1,5,10,15,25,50 \& 80 \mu 1$ against dist. $\mathrm{H}_{2} \mathrm{O}$ : $99,95,90,74,50 \& 20 \mu 1$ respectively). The preparing standards ppAb-AuNPs conjugated samples in form of conjugates with dist. $\mathrm{H}_{2} \mathrm{O}$ (conjugates $3,10,15 \& 20 \mu$ against dist. $\mathrm{H}_{2} \mathrm{O}: 97,90,85 \& 80 \mu 1$ respectively) and $5 \mathrm{ml}$ of diluted dye (phosphoric acid and methanol) was mixed with both preparations and the color absorbance was measured at $595 \mathrm{~nm}$ for each standard tube being planned on standard curve for protein content measurement calculation.

Patients sampling: Blood samples were kindly collected from human cases, Benha University Hospital, Benha Teaching Hospital, Kasr Eleni University Hospital, Aboelresh Pediatrics Hospital, Ain Shams University Hospital, and Theodore Bilharz Institute Hospital from March 2016 to October 2017 and manipulated in immuno-parasitology department of TBRI, Giza.

Samples $5 \mathrm{ml}$ were divided into 3 groups: G1: 27 blood samples from proved hydatid osis patients by US, CT, IHAT and cyst surgical excision. G2: 20 blood samples from $H$. nana, E. vermicularis, and/or $F$. giganti$c a$ infected patients and hydatidosis-free (cross-reactivity group). G3: 20 blood samples from apparently normal individuals; workers and official hospital personnel (control group). Samples were allowed to clot for $2 \mathrm{hrs}$ at room temperature to separate serum and kept at- $20^{\circ} \mathrm{C}$ until used.

Demographic data: Medical sheets were collected about age (from 11 to 60 years), sex (male or female), residence (rural or urban), and occupation. Clinical presentation (symptoms, signs and organs affected) and personal hygiene (washing hands, vegetables $\&$ contact with dogs) data were recorded in addition to data from patients' sheets as cyst size, treatment, IHAT laboratory result, a titer above 1/160 was considered positive.

Surgically removed cysts from different organs (liver, spleen, and lung) of patients attended the above-mentioned hospitals, were sent to the pathology department of TBRI for histopathological examination of the cyst wall and hydatid fluid.

Detection of $\mathrm{pAg}$ in serum samples by sandwich ELISA: Coating of polystyrene microtiter plates wells (96-flat bottom wells, M 129A Dynatehc, Telangana, India) with 100 $\mu \mathrm{l}$ of a $20 \mu \mathrm{g} / \mathrm{ml}$ concentration of purified IgG ppAb and incubated at room temperature for overnight, then washing 3 times with $0.1 \mathrm{M} \mathrm{PBS} / \mathrm{T}$, and $\mathrm{pH}$ was maintained at 7.4. Free sites in wells were blocked with $200 \mu 1$ / 
well of BSA, $\mathrm{pH}$ at 7.4 for $2 \mathrm{hrs}$ at $37^{\circ} \mathrm{C}$, and washed 3 times with buffer. Sera, each of $100 \mu \mathrm{l} /$ well were added to wells, incubated for $2 \mathrm{hrs}$ at $37^{\circ} \mathrm{C}$, and then wells were washed 3 times. IgG ppAb conjugated with HRP in PBS/T $(1 / 10 \mu \mathrm{g} / \mathrm{ml})$ was added by $100 \mu \mathrm{l} /$ well for $1 \mathrm{hr}$ at room temperature, then wells were washed 3 times with buffer. Substrate solution (one O-phenylene diamine-dihydrochloride OPD tablet dissolved in $25 \mathrm{ml}$ of $0.05 \mathrm{M}$ phosphate citrate buffer) was added by $100 \mu \mathrm{l} /$ well for $30 \mathrm{~min}$. in dark at room temperature, $50 \mu \mathrm{l} /$ well of $8 \mathrm{~N} \mathrm{H}_{2} \mathrm{SO}_{4}$ was added to stop enzyme-substrate reaction and absorbance was measured at $492 \mathrm{~nm}$ by the ELISA reader (Richmond, CA, USA). According to the manufacture's protocol, antigen titer below 0.26 was negative and above 0.26 was positive; cut-off value was mean OD of negative controls $+2 \mathrm{SD}$.

Detection of circulating $\mathrm{pAg}$ in sera by a nanogold sandwich ELISA: Coating of polystyrene microtiter plates wells colored white for optical absorbance, was done with 100 $\mu 1$ of $20 \mu \mathrm{g} / \mathrm{ml}$ concentration of purified IgG ppAb conjugated with AuNPs representing a capture antibody, diluted in $0.1 \mathrm{M}$ carbonate buffer, $\mathrm{pH} 9.6$ for an overnight at room temperature, and then washed 3 times with 0.1 $\mathrm{M}$ PBS/T, pH 7.4. Blocking of wells was done by $100 \mu \mathrm{l} /$ well $0.1 \mathrm{BSA}$ for $2 \mathrm{hrs}$ at $37^{\circ} \mathrm{C}$, and washed 3 times with PBS/T. Tested sera $(100 \mu 1)$ were pipetted into wells, incubated for $2 \mathrm{hrs}$ at $37^{\circ} \mathrm{C}$, and washed 3 times and continued as above.

Statistical analysis: Data were tabulated and analyzed using SPSS (statistical package for social science) version 16. Significance was adopted at $\mathrm{P}<0.05$. Chi-square test $\left(\mathrm{X}^{2}\right)$ and fisher exact test (FET) were used for groups comparing categorical data. ROC curve assessed validity of diagnostic sensitivity, specificity and predictive values (Gonzalez-Sapienza et al, 2000). Probability: if $\mathrm{P}$ $>0.05$ (non-significant), if $\mathrm{P} \leq 0.05$ (significant) and if $\mathrm{P}<0.01$ (highly significant). Accuracy was detected by agreement percentage between sensitivity and specificity, positive and negative predictive values.

Ethics approval: The Scientific Research Ethical Committee, Faculty of Medicine, Benha University (2016) approved the work. Before taking samples, a written informed consent was obtained from all patients. The animal involved was in line with the Ethical Committee of Theodor Bilharz Research Institute approval (TBRI) and under the ethical guidelines by the Ethical Committee of the Federal Legislation and NIH Guidelines.

\section{Results}

Hydatid cyst wall showed protoscolices, germinal layer and laminated layer while the fluid showed scattered hooks, multiple invaginated protoscolices with hooks and evaginated protoscolices appearing with the suckers, rostellum with its hooks and body region (Fig. 1).

Hydatid infection in males $(51.9 \%)$ was higher than in females $(48.1 \%)$, with highest ages were 21-30 years with a total of $37.03 \%$ in both sexes and lowest infected ages were 11-20 years and 51-60 years with a total of $3.7 \%$ (Tab. 1).

Rural areas cases were higher $(70.37 \%)$ than urban ones $(29.63 \%)$, as to animal contact the patients were $59.26 \%$, and those eating unwashed raw vegetables were $55.56 \%$. Infected farmers were (48.15\%). IHAT showed positivity ( $1 / 160$ or more) in $51.9 \%$ of 25 infected cases and 2 cases were IHAT negative (Tab. 2).

Main symptom was right hypochondriac pain with $(77.78 \%)$ liver affection followed by $(14.81 \%)$ spleen affection, and $(7.41 \%)$ lung affection (Tab. 3).

Sandwich ELISA in G1 showed positivity in 22 sera $(81.48 \%)$ with significant difference by using the nanogold sandwich ELISA technique the positivity in hydatidosis group reached to 26 sera $(96.3 \%)$ with significant difference. In G2 (cross-reactivity group) sandwich ELISA was positive (20\%), but nanogold sandwich ELISA was (5\%) positive (Tab. 4). Sensitivity of nano-gold sandwich ELISA was higher than sandwich ELISA in detection of protoscolices antigen 
(96.3\% vs. $81.5 \%)$, validity tests were higher in nanogold sandwich ELISA than in sandwich ELISA; specificity (95\% vs. $80 \%$ ), positive predictive value (96.3\% vs. $84.6 \%)$, negative predictive value (95\% vs. $76.2 \%$ ) and accuracy ( $95 \%$ vs. $80.9 \%$ ), as (Fig. 2).

Table 1: Age and sex distributions of hydatid infected human cases:

\begin{tabular}{|c|c|c|c|c|c|c|c|c|}
\hline \multirow{2}{*}{$\begin{array}{l}\text { Ages } \\
\text { in years }\end{array}$} & \multicolumn{2}{|r|}{ Male } & \multicolumn{2}{|c|}{ Female } & \multirow{2}{*}{$\begin{array}{l}\text { Total } \\
\text { No. }\end{array}$} & \multirow{2}{*}{$\begin{array}{l}\text { Total } \\
\text { Percentage }\end{array}$} & \multirow{2}{*}{$\begin{array}{l}\text { FET } \\
\text { test }\end{array}$} & \multirow{2}{*}{$\begin{array}{l}\mathrm{P}- \\
\text { value }\end{array}$} \\
\hline & No. & Percentage & No. & Percentage & & & & \\
\hline $11-20$ & 1 & $3.70 \%$ & 0 & $0 \%$ & 1 & $3.7 \%$ & \multirow{6}{*}{3.05} & \multirow{6}{*}{0.68} \\
\hline $21-30$ & 6 & $22.2 \%$ & 4 & $14.8 \%$ & 10 & $37 \%$ & & \\
\hline $31-40$ & 2 & $7.4 \%$ & 4 & $14.8 \%$ & 6 & $22.2 \%$ & & \\
\hline $41-50$ & 4 & $14.8 \%$ & 5 & $18.51 \%$ & 9 & $33.3 \%$ & & \\
\hline $51-60$ & 1 & $3.7 \%$ & 0 & $0 \%$ & 1 & $3.7 \%$ & & \\
\hline Total & 14 & $51.85 \%$ & 13 & $48.15 \%$ & 27 & 100 & & \\
\hline
\end{tabular}

Table 2: Personal history and IHA test results of hydatid infected human cases:

\begin{tabular}{|c|c|c|c|c|}
\hline \multicolumn{2}{|l|}{ Personal data } & No. & $\%$ & Total hydatidosis cases \\
\hline \multirow[t]{2}{*}{ Residence } & Urban & 8 & 29.63 & \multirow[b]{2}{*}{27} \\
\hline & Rural & 19 & 70.37 & \\
\hline \multirow{2}{*}{$\begin{array}{l}\text { Animal contact (dogs \& } \\
\text { cats) }\end{array}$} & Yes & 16 & 59.26 & \multirow[b]{2}{*}{27} \\
\hline & No & 11 & 40.74 & \\
\hline \multirow{2}{*}{$\begin{array}{l}\text { Consumption of unwash- } \\
\text { ed raw vegetables }\end{array}$} & Yes & 15 & 55.56 & \multirow[b]{2}{*}{27} \\
\hline & No & 12 & 44.44 & \\
\hline \multirow[t]{4}{*}{ Occupation } & Farmer & 13 & 48.15 & \multirow{4}{*}{27} \\
\hline & House wife & 8 & 29.63 & \\
\hline & Employee & 5 & 18.52 & \\
\hline & Student & 1 & 3.70 & \\
\hline \multirow[t]{3}{*}{ IHA test } & Positive & 14 & 51.9 & \multirow{3}{*}{27} \\
\hline & Negative & 11 & 40.74 & \\
\hline & Not requested & 2 & 7.41 & \\
\hline
\end{tabular}

Table 3: Clinical data of different affected organs in hydatid infected human cases:

\begin{tabular}{|c|c|c|l|c|}
\hline Affected organ & No. & Percent & Symptoms & No \\
\hline \multirow{3}{*}{ Liver } & \multirow{3}{*}{21} & \multirow{3}{*}{77.78} & Asymptomatic & 1 \\
\cline { 4 - 5 } & & & Right hypochondriac pain & 14 \\
\cline { 4 - 6 } & & & Abdominal colic & 3 \\
\cline { 4 - 6 } & & & Epigastric pain & 3 \\
\hline \multirow{2}{*}{ Spleen } & 4 & 14.81 & Asymptomatic & 3 \\
\hline Lung & 2 & 7.41 & Ceft hypochondriac pain & 2 \\
\hline Total & 27 & 100 & & 27 \\
\hline
\end{tabular}

Table 4: Sandwich ELISA and nanogold sandwich ELISA in detection of protoscolices antigen:

\begin{tabular}{|c|c|c|c|c|c|c|c|c|}
\hline \multirow[t]{3}{*}{ Groups } & \multicolumn{4}{|c|}{ Sandwich-ELISA } & \multicolumn{4}{|c|}{ Nano-gold sandwich-ELISA } \\
\hline & \multicolumn{2}{|c|}{ +ve cases } & \multicolumn{2}{|c|}{-ve cases } & \multicolumn{2}{|c|}{ +ve cases } & \multicolumn{2}{|c|}{-ve cases } \\
\hline & No. & Percent & No. & Percent & No. & Percent & No. & Percent \\
\hline Hydatidosis $(n=27)$ & 22 & 81.48 & 5 & 18.52 & 26 & 96.3 & 1 & 3.7 \\
\hline Cross-reactivity $(n=20)$ & 4 & 20 & 16 & 80 & 1 & 5 & 19 & 95 \\
\hline Control group $(n=20)$ & 0 & 0 & 20 & 100 & 0 & 0 & 20 & 100 \\
\hline $\mathrm{X} 2$ test, $\mathrm{P}$-value & \multicolumn{4}{|c|}{$36.37,<0.001 * *$} & \multicolumn{4}{|c|}{$59.05,<0.001 * *$} \\
\hline Sensitivity & \multicolumn{4}{|c|}{$81.5 \%$} & \multicolumn{4}{|c|}{$96.3 \%$} \\
\hline Specificity & \multicolumn{4}{|c|}{$80 \%$} & \multicolumn{4}{|c|}{$95 \%$} \\
\hline PPV & \multicolumn{4}{|c|}{$84.6 \%$} & \multicolumn{4}{|c|}{$96.3 \%$} \\
\hline NPV & \multicolumn{4}{|c|}{$76.2 \%$} & \multicolumn{4}{|c|}{$95 \%$} \\
\hline Accuracy & \multicolumn{4}{|c|}{$80.9 \%$} & \multicolumn{4}{|c|}{$95 \%$} \\
\hline
\end{tabular}

\section{Discussion}

In the present study, infected males were higher than females. This agreed with Salama et al. (2014) who found that hydatidosis was higher in males $(72.03 \%)$ than in females $(27.96 \%)$, due to many exposure to infective sources as dogs, soil (Rakhshanpour et al. (2012) and/or eating raw vegetables or consumption of contaminated water (Khazaei et al, 2016),

In the present study, hydatidosis was high among age group 21-30 years. Salama et al. (2014) found that $4^{\text {th }}$ decade $(46.7 \%)$ was the highest; Chalechale et al. (2016) found 
that the age group 21-40 years (41.2\%) was the most affected, and Abdulhameed et al. (2018) showed that the $3^{\text {rd }}$ decade or youth group was highest $(26.9 \%) \mathrm{CE}$ infected one.

In the present study, high hydatidosis was in rural areas. This agreed with El-Shazly et al. (2007) in Egypt, Acosta-Jamett et al. (2014) in Chile, and Chalechale et al. (2016) in Iran.

In the present study, the liver was the commonest affected site. This agreed with Salama et al. (2014) in Egypt, Chalechale et al. (2016) in Iran, Also Abdulhameed et al. (2018) in Iraq particularly the right upper quadrant causing abdomen pain. El-Ghareeb et al. (2016) reported asymptomatic hepatic hydatidosis patients $(20.5 \%)$ as well as pulmonary ones $(21.7 \%)$, but El-Sayed et al. (2020) reported symptomatic lung patients presented with chronic cough (sometimes with accompanied with hemoptysis or evacuation of cyst material), chest pain, pleuritis or dyspnea, with more than one sign and symptoms in same patient mainly with lung infection. The clinical variations could due to variable sizes and sites of hydatid cysts exerting different mass effects on surrounding organs and complications (WHO, 2019).

The nanogold particles to detect ELISA antibodies increased sensitivity and specificity (Ciaurriz et al, 2017).

In the present study, ppAb were loaded on nanogold particles in sandwich ELISA as a new combination to diagnose hydatidosis circulating antigens, but lateral flow dipstick assay was used (Khanbabaie et al, 2019) to conjugate IgG fractions on gold nanoparticles. Dot-immunogold staining method detected antibodies against sheep hydatidosis by antigen B labeled with gold nanoparticles and analyzed by SDS-PAGE, nanoparticles gave a typical purple color by binding at immunoreaction site strip (Jahan et al, 2014).

In the present study, nanogold sandwich ELISA gave sensitivity \& specificity; $96.3 \%$ \& $95 \%$ versus $81.5 \%$ \& $80 \%$ by sandwich ELISA. This agreed with Koura et al. (2015) who used paramagnetic nanoparticles to de- tect human protoscolices antigen and found that paramagnetic sandwich ELISA showed $95.2 \%$ sensitivity \& specificity $95.5 \%$, and ordinary sandwich ELISA showed sensitivity $90.48 \%$ \& specificity $91.3 \%$. The present result disagreed with Bauomi et al. (2015) who found $52.5 \%$ sensitivity by ELISA for human circulating protoscolices antigen.

In the present study, nanogold sandwich ELISA positive predictive value (96.3\%) was higher that sandwich ELISA (84.6\%). Predictive value in immunodiagnosis proved effective in epidemiology as low value indicated confidence lack (Allsopp et al, 1987).

In the present study, two Hymenolepis nana cases, one Entrobius vermicularis case \& one Fasciola gigantica gave false-positive results by sandwich ELISA (20\%), but one $H$. nana case gave false-positivity by nanogold sandwich ELISA (5\%). This was due to the common antigens shared between Hymenolepis and Echinococcus protoscolices antigens (Song et al, 2017). Sero-diagnosis hydatidosis gave poor clinical support due to cross-reactivity with other helminthes (Tawfeek et al, 2011). Cross-reaction was in few hydatidosis-free patients by indirect ELISA using antigen B (Sadjjadi et al, 2009). Falsepositivity was in taeniasis co-infected with hydatidosis (Mohammadzadeh et al, 2012). (Hernández-González et al, 2018) reported low cross-reactivity with alveolar hydatidosis patients with recombinant ELISA antige$\mathrm{ns}$, for antigen $\mathrm{B} 2 \mathrm{t}$, it gave $(9.5 \%)$ least one $\&$ for $2 \mathrm{~B} 2 \mathrm{t}$ antigen was $(16.7 \%)$ but highest one was with hydatid fluid immunochromatography (64.3\%). But, Hadj Rabia et al. (2018) did not find cross-reaction among patients with toxoplasmosis and hydatidosis.

\section{Conclusion}

Labeling of gold nanoparticles to sandwich ELISA test improved its sensitivity and specificity to detect human hydatid protoscolices antigen in sera and raised clinical diagnostic confirmation. Nanogold sandwich ELISA improved the test predictive value and recommended in epidemiological study.

Competing interest: Authors declared that 
they neither have conflict of interests nor received fund.

Author's contributions: All authors contributed to the design and organized the study. Amira SG Elghannam and Ibrahim RA Shalash collected specimens and contributed to the practical work. Samia M Rashed, Mona E Nasr, and Nagwa SM Ali shared in data analysis. Waleed E Elawamy shared in writing manuscript, experimental work and data analysis and contributed to the editing of manuscript for publication. All authors read and approved this manuscript.

\section{References}

Abdulhameed, MF, Habib, I, Al-Azizz, SA, Robertson, I, 2018: A retrospective study of hu man cystic echinococcosis in Basrah Province, Iraq. Acta Trop. 178:130-3.

Abraham, A, Kannangai, R, Sridharan, G, 2008: Nanotechnology:A new frontier in virus detection in clinical practice. Ind. J. Med. Microbiol. 26:297-301.

Acosta-Jamett, G, Weitzel, T, Boufana, B, Adones, C, Bahamonde, A, et al, 2014: Prevalence and risk factors for echinococcal infection in a rural area of northern Chile: A household-based cross-sectional study. PLoS Negl. Trop. Dis. 8:e3090.

Allsopp, B, Jones, A, Allsopp, M, Newton, S, Macpherson, C, 1987: Interspecific characterization of several taeniid cestodes by isoenzyme analysis using isoelectric focusing in agarose. Parasitology 95:593-601.

Aly, I, Zalat, R, El Aswad, B, Moharm, IM, Masoud, BM, Diab, T, 2013: Novel nanomagnetic beads based-latex agglutination assay for rapid diagnosis of human schistosomiasis haematobium. Int. J. Med. Hlth. Biomed. Pharm. Eng. 7:642-7.

Bauomi, I, El-Amir, A, Fahmy, A, Zalat, R, Diab, TJ, 2015: Evaluation of purified $27.5 \mathrm{kDa}$ proto- scolex antigen-based ELISA for the detection of circulating antigens and antibodies in sheep and hum-an hydatidosis. J. Helminthol 89: 577-83.

Bradford, MM, 1976: A rapid and sensitive method for the quantitation of microgram quantities of protein utilizing the principle of protein-dye binding. J. Anal. Biochem. 72:248-54.

Chalechale, A, Hashemnia, M, Rezaei, F, Sayadpour, M, 2016: Echinococcus granulosus in humans associated with disease incidence in domestic animals in Kermanshah, west of Iran. J. Parasit. Dis. 40:1322-9.

Chandrakesan, SD, Parija, SC, 2003: Latex agglutination test (LAT) for antigen detection in the cystic fluid for diagnosis of cystic echinococcosis. Diagn. Microbiol. Infect.Dis. 45:123-6.

Ciaurriz, P, Fernández, F, Tellechea, E, Moran, JF, Asensio, AC, 2017: Comparison of four funct-ionalization methods of gold nanoparticles for enhancing the enzyme-linked immunosorbent assay (ELISA). Beilstein J. Nanotechnol. 8:244-53.

El-Ghareeb, AS, Waked, NM, Al-Feky, HM, 2016: Clinical and parasitological studies on pulmonary and hepatic hydatid cysts in hospitalized children and adults. J. Egypt. Soc. Parasitol. 46:9-18.

El-Sayed, WMA, Abou-Bakr, AA, Morsy, T A, 2019: Oncogenic liver flukes acquired from eating raw or undercooked fish and crabs. J. Egypt. Soc. Parasitol. 49, 2:283-92

El-Shazly, AM, Awad, SE, Hegazy, MA, Mohammad, KA, Morsy, TA, 2007: Echinococcosis granulosus/hydatidosis an endemic zoonotic disease in Egypt. J. Egypt. Soc. Parasitol. 37, 2: 609-22.

Engvall, E, Perlmann, P, 1971: Enzyme-linked immunosorbent assay (ELISA) quantitative assay of immunoglobulin G. Immunochemistry 8: 871-4.

Fagbemi, BO, 1995: Development and characterization of a monoclonal antibody reactive with a $28 \mathrm{kDa}$ protease of Fasciola gigantica. Vet. Parasitol. 57:351-6.

Fathi, S, Jalousian, F, Hosseini, SH, Najafi, A, Darabi, E, et al, 2018: Design and construction of a new recombinant fusion protein ( $2 b 2 t+$ EPC 1) and its assessment for serodiagnosis of cystic echinococcosis. Apmis 126:428-39.

Gonzalez-Sapienza, G, Lorenzo, C, Nieto, A, 2000: Improved immunodiagnosis of cystic hydatid disease by using a synthetic peptide with higher diagnostic value than that of its parent protein, Echinococcus granulosus antigen B. J. Clin. Microbiol. 38:3979-83.

Hadj Rabia, S, Benmoussa, F, Benzaid, A, Baz, A, 2018: Hydatidosis: Preparation and evaluation of radiolabeled antigens and antibodies. Exp. Parasitol. 187:67-74.

Hermanson, G, 2008: Bioconjugate Techniques. Academic Press, San Diego.

Hernández-González, A, Sánchez-Ovejero, C, 
Manzano-Román, R, Sánchez, MG, Delgado, JM, et al, 2018: Evaluation of the recombinant antigens $\mathrm{B} 2 \mathrm{t}$ and $2 \mathrm{~B} 2 \mathrm{t}$, compared with hydatid fluid, in IgG-ELISA and immunostrips for the diagnosis and follow up of CE patients. PLoS Negl. Trop. Dis. 12, e0006741.

Ibrahim, EA, Morsy, TA, 2020: Tissue sparing technique in liver hydatid diseases: Three-way technique versus hydatid cone technique. J. Egpypt. Soc. Parasitol. 50, 2:378-89

Iraqi, W, 2016: Diagnostic value of semi-purified antigens of hydatid cyst fluid in human cystic echinococcosis. Acta Parasitol. 61:144-50.

Jahan, N, Khatoon, R, Ahmad, S, 2014: A comparison of microscopy and enzyme linked immuno-sorbent assay for diagnosis of Giardia lamblia in human faecal specimens. J. Clin. Diagn. Res. 8:4-6.

Jeyathilakan, N, Basith, A, John, L, Chandran, NDJ, Dhinakarraj, G, 2014: Anion exchange chromatography for purification of antigen B of cystic echinococcosis. J. Chromatogr. Separ. Tech. 5:1-3.

Khanbabaie, S, Riazi, M, Chang, CH, Yunus, MH, Noordin, R, 2019: Lateral flow dipstick antigen assay for human cystic echinococcosis. Acta Trop. 190:171-6.

Khazaei, S, Rezaeian, S, Khazaei, Z, Goodarzi, E, Khazaei, S, et al, 2016: Epidemiological and clinical characteristics of patients with hydatid cysts in Khorasan Razavi Province, from 2011 to 2014. Iranian J. Parasitol. 11:364.

Koura, EA, Rabee, I, Ahmed RO, Mohamed, WA, 2015: Using of paramagnetic nanoparticles with immunomagnetic bead ELISA in diagnosis of hydatidosis (Echinococcus granulosus). World J. Pharma. Sci. 3:2372-9.

Mohammadzadeh, T, Sako, Y, Sadjjadi, SM, Sarkari, B, Ito, A, 2012: Comparison of the usefulness of hydatid cyst fluid, native antigen $B$ and recombinant antigen B8/1 for serological diagnosis of cystic echinococcosis. Trans. Roy. Soc. Trop. Med. Hyg. 106:371-5.

Mukherjee, P, Bhattacharya, R, Mukhopadhyay, D, 2005: Gold nanoparticles bearing functional anti-cancer drug and anti-angiogenic agent: A. J. Biomed. Nanotechnol. 1:224-8.

Nowotny, A, 1979: Basic Exercises in Immunochemistry: A Laboratory Manual. Springer, Berlin, Heidelberg.

Omar, M, Sultan, K, Haridy, M, Omran, A, 2013: Prevalence of cystic echinococcosis in slaughtered ruminants in different abattoirs, Upper
Egypt. Amer. J. Anim. Vet. Sci. 8:117-21.

Pagnozzi, D, Addis, MF, Biosa, G, Roggio, A M, Tedde, V, et al, 2016: Diagnostic accuracy of antigen 5-based ELISAs for human cystic echinococcosis. PLoS Negl. Trop. Dis. 10: e0004585.

Rafiei, A, Craig, PS, 2002: The immunodiagnostic potential of protoscolex antigens in human cystic echinococcosis and the possible influence of parasite strain. Ann. Trop. Med. Parasitol. 96:383-9.

Rakhshanpour, A, Harandi, MF, Moazezi, S, Rahimi, M, Mohebali, M, et al, 2012: Seroprevalence of human hydatidosis using ELISA method in Qom province, central Iran. Iran. J. Parasitol. 7:10-4.

Sadjjadi, SM, Sedaghat, F, Hosseini, SV, Sarkari, B, 2009: Serum antigen and antibody detection in echinococcosis: Application in serodiagnosis of human hydatidosis. Korean J. Parasitol. 47:153-7.

Salama, AA, Othman, AA, Zayed, HA, 2014: Cystic echinococcosis in the middle region of $\mathrm{Ni}$ le Delta, Egypt: Clinical and radiological characteristics. Egypt. J. Radiol. Nucl. Med. 45: 641-9. Smith, AM, Dowd, AJ, McGonigle, S, Keegan, PS, Brennan, G, et al, 1993: Purification of a cathepsin L-like proteinase secreted by adult Fasciola hepatica. Mol. Biochem. Parasitol. 62: 1-8.

Song, X, Hu, D, Yan, M, Wang, Y, Wang, N, et al, 2017: Molecular characteristic and serodiagnostic potential of dihydrofolate reductase from Echinococcus granulosus. Sci. Rep. 7, 1: 514.

Tawfeek, GM, Elwakil, HS, El-hoseiny, L, Thabet, HS, Sarhan, RM, et al, 2011: Comparative analysis of the diagnostic performance of crude sheep hydatid cyst fluid, purified antigen $\mathrm{B}$ and its subunit (12 Kda), assessed by ELISA, in the diagnosis of human cystic echinococcosis. Parasitol. Res. 108:371-6.

Tijssen, P, Kurstak, E, 1984: Highly efficient and simple methods for the preparation of peroxidase and active peroxidase-antibody conjugates for enzyme immunoassays. Analy. Biochem.136:451-7.

WHO, 2019: Echinococcosis campaign in Eastern Europe, Geneva.

Wisdom, GB, 2009: Horseradish peroxidase labeling of IgG antibody. In: Protein Protocols Handbook. Springer, Humana Press, Totowa, NJ. Zhou, Y, Pan, FG, Li, YS, Zhang, YY, Zhang, 
JH, Lu, SY, et al, 2009: Colloidal gold probebased immunochromatographic assay for the rapid detection of brevetoxins in fishery product samples. Biosens, Bioelectron. 24:2744-7.

\section{Explanation of figures}

Fig. 1: Surgical removed: Associated keys/annotations: A) Multiple invaginated protoscolices with hooks. B) An invaginated protoscolex with hooks (red arrow). C) E. granulosus hooks. D) Hydatid cyst wall: laminated layer (red arrow), germinal layer (blue arrow) and scolices (green arrow). E) Evaginated protoscolex showing the suckers, rostellum with its hooks and body region (posterior part).

Fig. 2: ROC curve: Sensitivity and specificity of sandwich ELISA vs. nanogold sandwich ELISA for hydatidosis antigen in human cases.
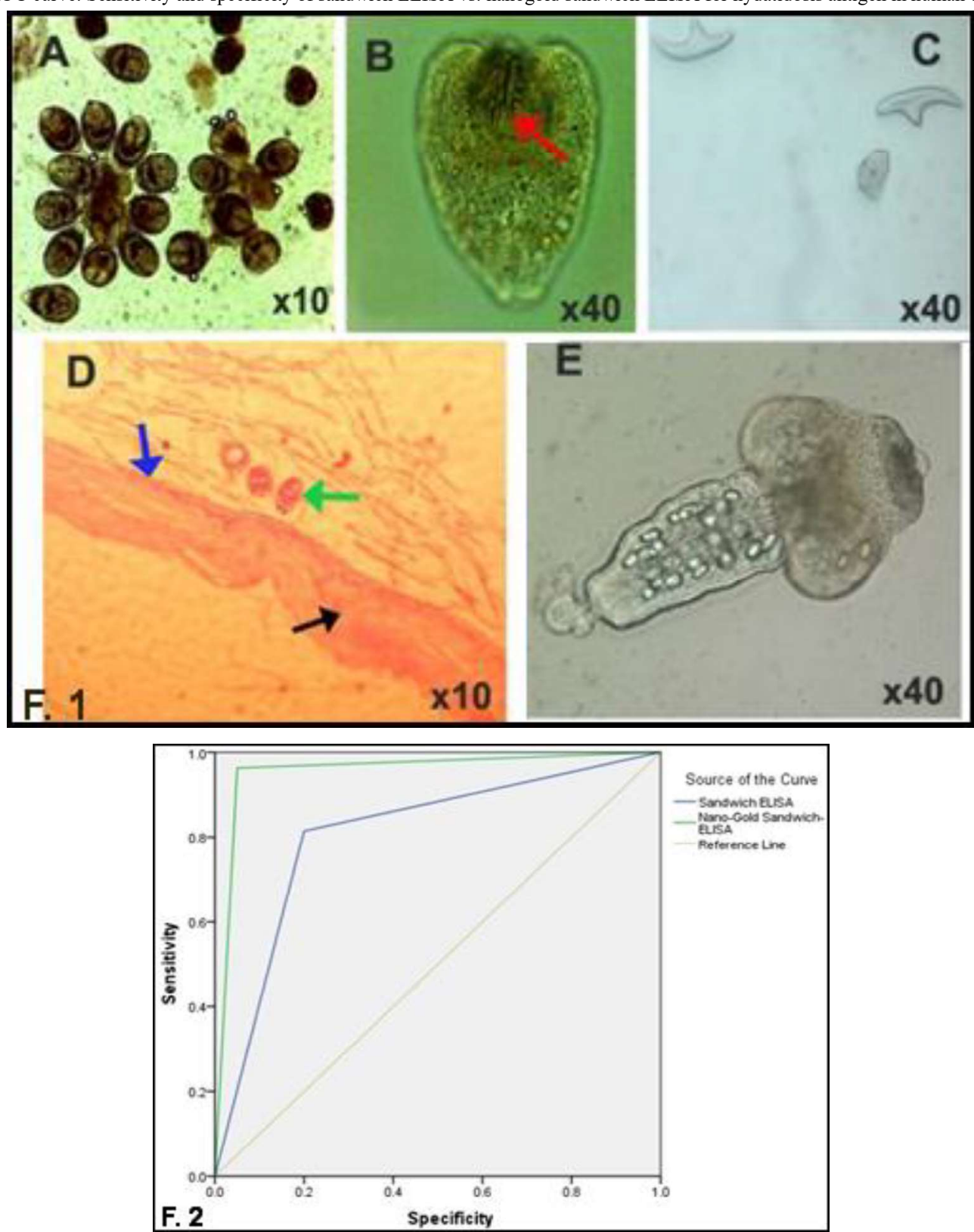